\title{
On the Effect of Online Formative Assessment on Iranian Lower Intermediate EFL Learners Reading Comprehension
}

\author{
Farideh Peyghambarian (Corresponding author) \\ English Department, Islamic Azad University, Torbat -e Heydarieh branch , Iran \\ E-mail: faridehpeyghambarian@yahoo.com \\ Mohammad Ali Fatemi \\ English Department, Islamic Azad University, Torbat -e Heydarieh branch, Iran \\ E-mail: matorbat@gmail.com \\ Hamid Ashraf \\ English Department, Islamic AzadUniversity, Torbat -e Heydarieh branch, Iran \\ E-mails:maeltiau@gmail.com
}

Received: 16-08-2014

Accepted: $30-10-2014$

Published: 01-03-2015

doi:10.7575/aiac.ijalel.v.4n.2p.189

URL: http://dx.doi.org/10.7575/aiac.ijalel.v.4n.2p.189

\begin{abstract}
Online Formative Assessment (OFA) improves EFL students' reading comprehension enabling them to have a better performance in reading comprehension tests. To lend support to the above mentioned claim, a quasi-experimental study was conducted in Mashhad, Iran. 48 female lower intermediate EFL students took part in this study. Participants were assigned to control and treatment groups. Participants in both groups received a formative assessment program lasting for 10 sessions. Formative assessment in treatment group was conducted by the site itself, and participants in control group were assessed by the teacher. It was found that participants in treatment group significantly outperformed those in control group. This finding indicated OFA as an effective learning tool in EFL reading comprehension classrooms.
\end{abstract}

Keywords: online formative assessment, Reading comprehension, EFL intermediate learners

\section{Introduction}

English as foreign language (EFL) students need to be assessed so that their teachers can realize their strengths and weaknesses. There exist two kinds of assessments in EFL literature, namely formative and summative, which are commonly employed by EFL teachers. Summative assessment (SA), known as assessment of learning, requires some form of grading or ranking of students' abilities or achievements related to goals. Formative assessment (FA), on the other hand, is called assessment for learning; FA is about what teachers and students can do to document the students' learning so that they can utilize this information to enhance their learning process(Douglas,2010, as cited in Lindqvist \& Shuja, 2013). FA is process-based, and is used to assess students' learning in the classroom usually in order to keep records of their achievement overtime (Harris, 2007). FA is a common classroom procedure which emphasizes upon the learning process and it is by nature diagnostic, remedial, regulatory, ongoing, self-regulating, timely and accurate (Cizek, 2010). FA occurs when teachers help their students understand their own learning in ways enabling them to learn better, design their learning process by doing something with the information conveyed to them in a comprehensible language (Restrepo, 2012). Given the benefits of OFA, the present study aims at investigating the effect of online formative assessment (OFA) on the development of Iranian lower intermediate EFL learners' reading comprehension.

\section{Review of Literature}

Rakhyoot and Weir (n.d.) in article" On-Line Formative Assessments" introduced a modern model of FA based on internet to investigate the effect of on-line formative assessment (OFA) and feedback in the setting of an EFL course for postgraduate students at the University of Strathclyde.

It was found that the participants in OFA1 (OFA with in-question feedback) group outperformed those in the control group in the post-test; (2) OFA1 and OFA2 (OFA without any in-question feedback) groups that interacted with the online facility outperformed the control group that had no interaction with the system; (3) OFA1 group that interacted with OFA with the added in-question feedback features outperformed OFA2 group who employed the OFA version but without feedback. In addition, participants in OFA1 displayed more positive responses on the influence of the OFA in improving English grammar, and vocabulary skills. The employment of penalties as part of the feedback to encourage quiz reattempts was confirmed by both OFA1 and OFA2 students. 
In another insightful study, Chetchumlong (2010) investigated the effects of web-based FA (WBFA) on students' listening achievement and determined students' attitudes toward it. As Chetchumlong (2010) believes lecturers must confront the excessive resource demands, increasing time and workloads for marking required by the current conventional paper-and-pencil FA. Therefore, it is expected that the employment of WBFA in the course would be a more effective approach to alleviate the problem and help enhance the students' listening achievement. It is also expected that WBFA would encourage EFL students to have positive beliefs on it (Chetchumlong, 2010).

Yaghoobi and Mashhadi (2013) in their study investigated the effect of Formative Testing on Iranian English language learners' achievement. It was found that there was a significant difference in the level of achievement of the treatment group compared to the control group in the summative test since FA provides teachers with feedback to modify learning activities and experiences (Huhta, 2010); it enhances self-assessment in learning; it provides opportunities to bridge the gap between current and desired performance; it makes clear good performances, including goals, criteria, and expected standard; it improves learners' meta-cognitive awareness of how they learn (Shepard 2005).

Moreover, Yaghoobi and Mashhadi (2013) enumerate a list of implications for EFL teachers to utilize FA in their language class as following:

- They can inform students of their current achievement in order to help them set goals for improvement.

- They can realize their instruction needs and try to meet them.

- They recognize the full range of all learners' achievements.

In addition, students' motivation in learning increases and they can learn valuable lifelong skills, such as selfevaluation, self-assessment, and goal settings (Yaghoobi \& Mashhadi, 2013).

The problem this study aims to discuss and address is barriers EFL learners experience in reading classrooms. The researcher sought to design an environment where teacher-student and student-student interactions increase. The researcher proposed an online formative assessment model based on which EFL students could answer to some reading comprehension being available on the internet. Students were simultaneously informed of their performances.

The present study is significant since it introduces an online model of FA through which EFL students can improve their reading comprehension. EFL teachers can benefit from the results in utilizing CALL in their language classrooms. EFL students, also, can take benefits from the present study and the model to use internet as an effective learning tool in order to improve their reading comprehension. Curriculum designers and material developers in EFL can integrate CALL into traditional programs.

\section{Method}

\subsection{Participants}

The participants of this study were 48 Iranian lower intermediate students studying Touchstone 1, who had been selected from among a group of EFL learners in a Language Institute, in Mashhad, Iran. Sample selection was conducted based on Quick Placement Test; that is the participants scored 24-30 out of 40. The participants' age ranged from 18 to 24 years. Only females took part in this study. These participants were randomly assigned to control $(\mathrm{N}=24)$ and experimental $(\mathrm{N}=24)$ groups.

\subsection{Instrumentations}

\subsubsection{Quick placement test (QPT)}

To select participants with the same level of language proficiency, QPT developed by Oxford University Press and Cambridge ESOL and was administered to 90 EFL learners at the start of the study. The test includes 60 multiplechoice items in two parts. Part 1 has 40 multiple-choice items and Part 2 has 20 multiple-choice items. Part 1 is taken by all candidates and is aimed at lower intermediate learners. Concerning the participants of the present study, (lowerintermediate) only the first part was administered.

\subsubsection{Reading test battery}

In addition to QPT, participants in both groups had to answer some reading questions which have been developed in a multiple-choice format as the pretest as well as the posttest. The test included four passages and totally 20 comprehension items had been designed ( 5 items per text). To calculate its reliability, it was first piloted with a group of lower-intermediate EFL students in Mashhad, Iran. Having calculated Cronbach's Alpha it was shown that the test enjoyed a relatively high reliability $(\alpha=.79)$.

\subsection{Materials}

Throughout the course (10sesions) the participants in control group received some printed reading texts. They were required to read and answer the comprehension questions. Participants in the experimental group received the same reading passages on the internet being available at http://www.esolcourses.com/content/topicsmenu/reading.html. For example, such reading texts as 'Bonfire Night', Halloween, and St Andrew's Day were practiced during the course.

\subsection{Procedure}

Based on a placement test (Quick Placement Test) 48 female lower-intermediate EFL students were selected and randomly assigned to experimental $(\mathrm{N}=24)$ and control $(\mathrm{N}=24)$ groups. Participants in experimental group receive required instructions on how to utilize internet as a source of EFL reading texts and to answer comprehension questions designed at the end of every text. 
Throughout the course (10 sessions) the teacher provided both groups with the same reading texts. These two groups received the reading texts in different ways, that is, those in experimental group practiced the texts being available on the internet (http://www.esolcourses.com/content/topicsmenu/reading.html). On the other hand, participants in control group practice printed reading texts. The process of reading the texts and answering the questions was only done by the students themselves in both groups. Scores obtained by the participants in experimental group were every session determined by the site and participants in control group were scored by the EFL teacher.

Finally, the posttest being the same as the pretest was administered. Having employed SPSS the collected data were analyzed and the results are discussed in next section.

\section{Data analysis}

Having collected the required data according to the mentioned data collection instruments and procedures, the researchers analyzed the data and tested the hypothesis formulated for the study.

\subsection{Reliability and Validity of reading test battery}

The validity of a test is the extent to which it assesses what it purports to assess and nothing else. The items included in the test were both textually explicit and inferential questions and were related to the text. To make sure that the reading test is reliable, Cronbach's Alpha was calculated (Table 1).

Table 1. Results of reliability

\begin{tabular}{lll}
\hline Test & N of items & Cronbach's Alpha \\
Reading & 20 & .79 \\
\hline
\end{tabular}

As Table 1 indicates, a relatively high reliability index was found for the reading comprehension test battery $(\alpha=.79)$.

Table 2 shows results of independent samples t-test for pretest.

Table 2. Results of independent samples t-test (pre-test)

\begin{tabular}{lllllll}
\hline Group & $\mathrm{N}$ & $\mathrm{M}$ & $\mathrm{SD}$ & $\mathrm{df}$ & $\mathrm{t}$ & sig \\
Cont. & 24 & 12.62 & 2.20 & 46 & 1.18 & .243 \\
Exp. & 24 & 11.75 & 2.87 & & & \\
\hline
\end{tabular}

As Table 2 shows, the difference between means of control $(\mathrm{N}=24, \mathrm{M}=12.62, \mathrm{SD}=2.20)$ and experimental ( $\mathrm{N}=24$, $\mathrm{M}=11.75, \mathrm{SD}=2.87)$ groups in reading comprehension pretest is not statistically meaningful $(\mathrm{df}=46, \mathrm{t}=1.18$, $\operatorname{sig}=.243>.05)$. The data confirmed that the participants were at the same level of language proficiency in EFL reading comprehension at the outset of the study.

To test the null-hypothesis of the present quasi-experimental study "Online formative assessment does not have any significant effect on Iranian lower-intermediate EFL learners' reading comprehension" independent samples t-test was again conducted (Table 3).

Table 3. Results of independent samples t-test (posttest)

\begin{tabular}{lllllll}
\hline Group & $\mathrm{N}$ & $\mathrm{M}$ & $\mathrm{SD}$ & $\mathrm{df}$ & $\mathrm{t}$ & sig \\
Cont. & 24 & 13.00 & 2.30 & 46 & 2.29 & .026 \\
Exp. & 24 & 14.91 & 3.37 & & & \\
\hline
\end{tabular}

As Table 3 shows, there is a statistically significant difference $(\mathrm{df}=46, \mathrm{t}=2.29$, sig $=.026<.05)$ between means of control $(\mathrm{N}=24, \mathrm{M}=13.00, \mathrm{SD}=2.30)$ and experimental $(\mathrm{N}=24, \mathrm{M}=14.91, \mathrm{SD}=3.37)$ groups in reading comprehension posttest. Accordingly, the null-hypothesis was rejected indicating that employing OFA has significant effects on development of EFL reading comprehension among these participants.

\section{Discussion and conclusion}

The present study sought mainly to explore the effects of an online formative assessment on Iranian lower-intermediate EFL learners' reading comprehension. Results of independent samples t-test showed that participants in treatment group (OFA) outperformed those in control group. According to the present finding which had been previously supported by Rakhyoot and Weir (n.d.) with respect to English grammar, and vocabulary skills. Implementation of formative assessment in an online context can allow EFL learners to get more interested in reading the text and comprehending the main idea. Concerning a computer-assisted language learning (CALL) program in EFL contexts, Marzban (2011) came to the conclusion that the employment of computer assisted educational techniques can enhance students' reading comprehension. EFL teachers can provide their students with different sites on the internet where they can read 
different authentic English texts followed by some comprehension questions. EFL students' comprehension ability can be immediately tested by the site and they can become aware of their total scores. EFL students need to update their information and equip themselves with modern technological tools to develop their learning independently from their teachers.

Like any other study undertaken so far, the present one is not exempt from limitations. For example, only formative assessment was taken into account and the effect of summative assessment was excluded. EFL reading comprehension was the only skill which was investigated and other language skills were not taken into consideration. Further research is needed to fill in the existing gaps. Concerning the participants, only female lower-intermediate EFL learners took part in the study and the findings may vary if applied to other groups.

\section{Acknowledgements}

I wish to take this opportunity and extend my thanks to Dr. Fatemi and Dr. Motallbzadeh and Dr. Ashraf who made the completion of the present study possible through their assistance.

\section{References}

Cizek, G. (2010). An introduction to formative assessment: History, characteristics, and challenges. In H. Andrade, \& G. Cizek (Eds.), Handbook of formative assessment (pp. 3-17). New York, NY: Routledge.

Chetchumlong, S. (2010). Effects of Web-Based Formative Assessment on Students' Listening Achievement and Attitudes in a Large EFL Class. In D. Gibson \& B. Dodge (Eds.), Proceedings of Society for Information Technology \& Teacher Education International Conference 2010 (pp. 46-51). Chesapeake, VA: AACE.

FREE English Lessons Online. http://www.esolcourses.com/content/topicsmenu/reading.html

Harris, L. (2007). Employing formative assessment in the classroom. Improving Schools, 10, 249-260.

Lindqvist, R., \& Shuja, J. (2013). Attitudes to assessment. teachers' attitudes towards assessment of English as a foreign language. [Online]. Retrieved from: http://dspace.mah.se.

Rakhyoot, W., \& Weir, G.R.S. (n.d.). On-Line Formative Assessments. Retrieved from:

http://www.cis.strath.ac.uk/cis/research/publications/papers/strath_cis_publication_2264.pdf.

Restrepo, H.N.A. (2012). Role of Systematic Formative Assessment on Students' Views of Their Learning. PROFILE, 15(2), 165-183.

Yaghoobi,M., \& Mashhadi, J. (2013). Probing the Impact of Formative Testing in Iranian English Language Learners upon their Enhancement. Journal of Basic and Applied Scientific Research, 3(2), 252-256. 